\title{
THE SOCIAL RESPONSIBLE PUBLIC PROCUREMENT IN EUROPEAN UNION IN THE CONTEXT OF IMPLEMENTATION IN LEGAL SYSTEM OF POLAND
}

\author{
[Společensky odpovědné zadávání veřejných zakázek v Evropské unii \\ v souvislosti s implementací do právního řádu Polské republiky] \\ Danuta Duda $^{1}$ \\ ${ }^{1}$ Slezská univerzita, Obchodně podnikatelská fakulta, Univerzitní nám. 1934/3, 73340 Karviná \\ Email:duda@opf.slu.cz
}

\begin{abstract}
This article deals with the social responsible public procurement and green public procurement in European union. The aim of this article is to explore history of the social responsible and green public procurement of the European union, the EU legislation in this area and apply it to practical examples in selected EU Member States (France, Great Britain, Sweden and Czech Republic). In Poland is the most important legislation of 29 January 2004 Public Procurement Law, where is listed also provision about social responsible and green public procurement. Socially responsible public procurement in Poland has been applied in many cities, such as: Gdynia, Gdansk, Bydgoszcz, Brzeziny, Bytom, Wrocław, Częstochowa, Szczecin, Toruń, Łódź and Kraków. The aim of this article is to also graphically present the level of EU green public procurement uptake in the EU in 2011, the level greening of public procurement in Poland in the years 2009-2012 or the level of social responsible public procurement in Poland in the years 2010-2012.
\end{abstract}

Keywords: European union, green public procurement, social responsible public procurement, socially responsible public procurement, the Public Procurement Office in Poland, public contracts.

JEL classification: K39

Doručeno redakci: 20.6.2014; Recenzováno: 8.7.2014; 24.7.2014; Schváleno k publikování: 23.9.2014

\section{Úvod}

Společensky odpovědné zadávání veřejných zakázek je legitimním nástrojem k dosahování sociálních a environmentálních cílů. Veřejní zadavatelé mohou být díky zodpovědnému a moudrému nakupování př́kladem pro firmy i jednotlivce, mohou efektivněji vynakládat veřejné prostředky a dosahovat multiplikačních efekti̊ investic. Společensky odpovědné zadávání veřejných zakázek je podporováno Evropskou komisí (Melková 2014, s. 5). Společensky odpovědné nebo jinak udržitelné zadávání veřejných zakázek můžeme rozdělit na sociálně odpovědné zadávání veřejných zakázek a ekologicky odpovědné zadávání veřejných zakázek. Sociálně odpovědné zadávání veřejných zakázek podporuje zaměstnání, pracovní právo a právo sociálního zabezpečení či sociální začleňování. Pokud se jedná o způsoby uplatnění sociálně odpovědného zadávání veřejných zakázek, tak je to vytváření pracovních míst pro osoby dlouhodobě nezaměstnané, vyhrazení do zadávacího řízení podmínku vytváření pracovních míst pro osoby se zdravotním postižením. Zvláštními kritérií pro získání zakázky může být také vytvoření přímých příležitostí pro zaměstnání místních obyvatel, zařazení místních malých a středně velkých podniků do dodavatelského řetězce a podpora obnovy dané obce/města či čtvrti. Ekologicky odpovědně zadávání veřejných zakázek by mělo považovat za přednostní uplatňování environmentálních kritérií a ochranu pracovníků ve stavebnictví před nabídkovou cenou. Dále např. pokud se jedná o veřejnou zakázku na stavební práce, tak ve zvláštních podmínkách na plnění veřejné zakázky může být požadavek vypracovat ekologicky odpovědné plány. Ekologicky odpovědné plány mohou směřovat $\mathrm{k}$ úsporám energií, zvýšení využívání recyklovaného papíru, zdokonalení systému 
třídění odpadů, úklidového režimu nebo nákupu výrobků splňujících kritéria značky „Ekologicky šetrný výrobek“.

Cílem článku „Společensky odpovědné zadávání veřejných zakázek v EU v souvislosti s implementací do právního řádu Polské republiky“ je zmapovat společensky odpovědné zadávání veřejných zakázek $\mathrm{vEU}$, charakterizovat právní předpisy $\mathrm{EU} \mathrm{z}$ této oblasti a představit jejich aplikaci na krátkých př́kladech ve vybraných členských státech EU: z Francie, Velké Británie, Švédska, České republiky a samozřejmě Polské republiky. V Polsku společensky odpovědné zadávání veřejných zakázek je upraveno v zákoně ze dne 29. ledna 2004 Prawo zamówień publicznych Dz. U. z 2010 r. Nr 113, poz. 759 Polské republiky, kde byla implementována př́slušná ustanovení ze směrnic EU zoblasti společensky odpovědného zadávání veřejných zakázek. Cílem tohoto článku je také představit, graficky znázornit a zhodnotit úroveň přijetí unijních kritérií z oblasti životního prostředí ve veřejných zakázkách v členských státech EU v roce 2011, úroveň ekologizace veřejných zakázek v Polsku v letech 2009-2012 či úroveň sociálně odpovědného zadávání veřejných zakázek v Polsku v letech 2010-2012. Článek se zabývá problematikou společensky odpovědného zadávání veřejných zakázek v letech 2009-2012 z důvodu skutečnosti, že novější údaje nejsou ještě k dispozici. V Polské republice je vydáván Národní akční plán pro udržitelné zadávání veřejných zakázek, kde se nachází vždy shrnutí posledních 3 let a plány na další 3 roky. Poslední akční plán je na období 2013-2016 a údaje týkající se společensky odpovědného zadávání veřejných zakázek jsou z let 2010-2012.

\section{Historie společensky odpovědného zadávání veřejných zakázek v Evropské unii}

První důležitější zmínka o společensky odpovědném zadávání veřejných zakázek byla v zelené knize z roku 1996 (Green Paper, Public procurement in the European Union: Exploring the way forvard), kde bylo mj. uvedeno, že pravidla pro zadávání veřejných zakázek by měly přispět $\mathrm{k}$ lepšímu dosažení sociálních a environmentálních cílů. Na základě výsledku debaty iniciované Zelenou knihou, Komise měla zvážit, jak lze lépe brát v úvahu sociální a environmentální aspekty při uplatňování pravidel při zadávání veřejných zakázek. V této zelené knize se nachází rovněž návaznost na čl. 2 Smlouvy o ES, kde se mimo jiné hovoří o podpoře $\mathrm{v}$ celém Společenství harmonického, vyváženého a udržitelného rozvoje hospodářských činností, vysoké úrovni zaměstnanosti a sociální ochrany, rovném zacházení pro muže a ženy, trvalém a neinflačním růstu, vysokém stupni konkurenceschopnosti a konvergenci hospodářské výkonnosti, vysoké úrovni ochrany a zlepšování kvality životního prostředí, zvyšování životní úrovně a kvality života, hospodářské a sociální soudržnosti a solidaritě mezi členskými státy. Dle zelené knihy zadavatelé mohou být vyzváni, aby prosazovali různé aspekty sociální politiky při zadávání veřejných zakázek, kdy zadávání veřejných zakázek je nástrojem, kterým lze výrazně ovlivnit chování hospodářských subjektů. Jako př́klady dosahování cílů sociální politiky je možné zmínit zákonné povinnosti týkající se ochrany zaměstnanců a pracovních podmínek v místě, kde se zakázka na stavební práce provádí. Rovněž politika ochrany životního prostředí se stala jednou z nejdůležitějších politik EU. Zelená kniha zmiňuje rovněž problematiku ochrany životního prostředí v souvislosti se zadáváním veřejných zakázek, kdy Evropskou unií bylo přijato více než 200 právních aktů, mimo jiné z oblasti posuzování a řízení kvality vnějšího ovzduší, řízení jakosti vod ke koupání, jakosti vody určené k lidské spotřebě, nakládání s odpady, bezpečnosti výrobků či posuzování vlivů některých veřejných a soukromých záměrů na životní prostředí. Bylo stanoveno, že požadavky na ochranu životního prostředí musí být zahrnuty do vymezení a provádění ostatních politik Společenství. Některé členské státy vyvinuly velmi pokročilou ochranu životního prostředí. 
Dalším důležitým aktem bylo interpretační sdělení Komise o právech Společenství platných pro zadávání veřejných zakázek a možnostech začlenění společenských hledisek do zadávání veřejných zakázek KOM (2001) 566 v konečném znění ze dne 15. 10. 2001. Cílem tohoto sdělení bylo „,vyjasnit rozsah možností začlenění sociálních hledisek do zadávání veřejných zakázek podle stávajícího právního rámce Společenství. Usilovalo zejména o zajištění dynamické a pozitivní interakce mezi ekonomickými, sociálními a zaměstnaneckými politikami, které se navzájem posilují‘. ${ }^{1}$

V roce 2000 vyhlásili v Lisabonu vedoucí činitelé Evropské unie za cíl vytvořit z EU do roku 2010 „,nejvíce konkurenceschopnou a nejdynamičtější ekonomiku světa, vybudovanou na znalostech, schopnou udržitelného hospodářského růstu, s větším počtem kvalitních pracovních př́ležitostí a s větší sociální soudržností“. Lisabonská strategie byla doplněna tř̌etím, environmentálním pilířem, když na svém zasedání v Göteborgu v roce 2001 přijala Evropská rada strategii udržitelného rozvoje EU. V roce 2002 přijaly Rada EU a Evropský parlament 6 . akční program pro životní prostředí, v němž je vytyčeno směřování EU v oblasti ochrany životního prostředí na prríštích deset let a jsou stanoveny čtyři prioritní oblasti, ve kterých je nutná urychlená akce (Schelleová, Pelikán 2014, s. 38).

A konečně v březnu 2004 byly vydány dvě směrnice k oblasti veřejných zakázek, konkrétně se jedná o směrnici Evropského parlamentu a Rady č. 2004/18/ES ze dne 31. března 2004, o koordinaci postupů při zadávání veřejných zakázek na stavební práce, dodávky a služby, ve znění pozdějších předpisů a o směrnici Evropského parlamentu a Rady č. 2004/17/ES ze dne 31. března 2004, o koordinaci postupů při zadávání zakázek subjekty působícími v odvětví vodního hospodářství, energetiky, dopravy a poštovních služeb, ve znění pozdějších předpisů.

\section{Společensky odpovědné zadávání veřejných zakázek v Evropské unii}

Ve výše zmíněných směrnicích najdeme samozřejmě rovněž příslušná ustanovení týkající se společensky odpovědného zadávání veřejných zakázek. V preambuli do směrnice Evropského parlamentu a Rady č. 2004/18/ES je, že zaměstnání a práce tvoří základní prvky pro zajištění rovnosti př́ležitostí pro všechny a přispívají $\mathrm{k}$ začlenění do společnosti. V této souvislosti přispívají chráněné dílny (tyto dílny, kde pracují lidé se zdravotním postižením, zajišt’ují různá občanské sdružení a jiné neziskové organizace) a programy chráněného zaměstnání účinným způsobem $\mathrm{k}$ začlenění nebo $\mathrm{k}$ opětovnému začlenění zdravotně postižených osob do trhu práce. Tyto dílny však nemusí být schopny získat zakázku za obvyklých podmínek hospodářské soutěže. Veřejní zadavatelé, kteří chtějí vymezit požadavky z hlediska životního prostředí v technických specifikacích dané zakázky, mohou stanovit požadavky z hlediska životního prostředí, jako je určitá výrobní metoda nebo konkrétní vliv skupin výrobků nebo služeb na životní prostředí.

V čl. 26 směrnice č. 2004/18/ES je uvedeno, že veřejní zadavatelé mohou stanovit zvláštní podmínky pro plnění zakázky za předpokladu, že jsou slučitelné s právem EU a jsou uvedeny v oznámení o zakázce nebo v zadávací dokumentaci. Podmínky, kterými se řídí plnění zakázky, se mohou týkat zejména sociálních faktorů a životního prostředí. Velmi důležitý je rovněž čl. 27 směrnice č. 2004/18/ES, kdy veřejný zadavatel v zadávací dokumentaci může, nebo stanoví-li tak členský stát, musí uvést subjekt nebo subjekty, od nichž může zájemce nebo uchazeč získat náležité informace o povinnostech týkajících se daní, ochrany životního prostředí, ochrany zaměstnanců a pracovních podmínek, které platí v členském státě, regionu

\footnotetext{
${ }^{1}$ Evropská komise, Sociálni nakupování. Prưvodce zohledňováním sociálních hledisek při zadávání veřejných zakázek, [online]. [vid. 14. června 2014]. Dostupné z: file:///C:/Users/uzivatel/Downloads/KE3210584CSC\%20(3).pdf
} 
nebo v místě, kde mají být prováděny stavební práce nebo poskytovány služby, a které platí pro stavební práce prováděné na místě a pro služby poskytované během plnění zakázky. Veřejný zadavatel, který poskytuje informace uvedené výše, požádá uchazeče nebo zájemce, kteří se účastní zadávacího řízení, aby uvedli, že při vypracování své nabídky vzali v úvahu povinnosti týkající se ochrany zaměstnanců a pracovních podmínek, které platí v místě, kde mají být provedeny práce nebo poskytnuta služba. Čl. 19 směrnice č. 2004/18/ES se zabývá již výše zmíněnými chráněnými dílnami, jsou to tzv. vyhrazené zakázky. Členské státy mohou vyhradit účast na zadávacím řízení chráněným dílnám nebo jim vyhradit plnění zakázek v rámci programů chráněného zaměstnání, kdy většina dotčených zaměstnanců jsou zdravotně postižené osoby, které $\mathrm{z}$ důvodu povahy nebo vážnosti svého postižení nemohou vykonávat pracovní činnost v běžných podmínkách.

Společensky odpovědné zadávání veřejných zakázek v členských státech EU je čím dál tím více rozšiřováno. Tento způsob zadávání veřejných zakázek je nejvíce uplatňován ve Francii, Velké Británii, Itálii, Belgii, Španělsku, Rakousku, Irsku, Dánsku, Nizozemsku či Švédsku. Ve Francii již v roce 2003 byla vypracována „Národní strategie udržitelného rozvoje“, v roce 2007 následoval „Národní akční plán udržitelného zadávání veřejných zakázek“. Francouzská vláda se zapojila do rozsáhlých konzultací se sociálními partnery - „rozpravy o životním prostředí“ a „rozpravy o začleněni““ - které pokrývají různá opatření s dopadem na sociální integraci, včetně zadávání veřejných zakázek. ${ }^{2}$ Městský úřad ve francouzském Angers zrrídil v roce 2005 interní kontaktní pozici (specializovaného právního poradce) pro ekologicky odpovědné zadávání veřejných zakázek a pověřil ho vypracováním postupů sociálně odpovědného zadávání veřejných zakázek s cílem vytvořit $\mathrm{z}$ nich plně zavedený postup při zadávacích činnostech městského úřadu (Melková 2014, s. 71). Město Lille podporuje své nákupčí $\mathrm{v}$ tom, aby vyhledávali náhradní produkty, jež omezují negativní vliv na životní prostř̌edí (Melková 2014, s. 72). Ve Velké Británii je nejrozš́řrenější sociálně odpovědné zadávání veřejných zakázek, které patři mezi vládní priority. V květnu 2005 byla vytvořena pracovní skupina pro udržitelné zadávání veřejných zakázek (SPTF), která se zabývala sociálními i ekologickými otázkami a v červnu 2006 vydala svůj akční plán. Akční plán předkládal obchodní př́pad pro udržitelné zadávání veřejných zakázek. ${ }^{3}$ Ve Velké Británii existuje např. Social Enterprise, což je britská organizace založená roku 2002 zastřešující sociální podniky, neziskové organizace a veřejnoprávní subjekty, které propagují sociální podnikání. Uplatnění sociálních a environmentálních kritérií u veřejných zakázek bylo např. v zakázce na stavbu nemocnice v Manchesteru či místní úřad v hrabství Devon vytvořil oznamovací a konzultační systém veřejného zadávání, který je vhodný pro širokou skupinu potenciálních dodavatelů, včetně možností zaměstnání pro nejvíce znevýhodněné skupiny. Švédsko: Švédský úrudad sociálního zabezpečení za účelem zajištění snadnějšího př́istupu k veřejným zakázkám pro malé a středně velké podniky, sociálně-ekonomické a dobrovolné organizace, které pracují se sociálně znevýhodněnými skupinami osob, občas zahrne účast těchto skupin do své úvodní studie o veřejné zakázce tak, aby získal lepší přehled o jejich specifických problémech při vypracování zadávací dokumentace. ${ }^{4}$ Švédské město Malmö má vypracovanou strategii zadávání veřejných zakázek, environmentální program do roku 2020 a definované environmentální požadavky na zadávání veřejných zakázek na stavební práce.

\footnotetext{
${ }^{2}$ Evropská komise, Pracovni dokument pro zaměstnance Komise, sociálně citlivé nakupování: průvodce jak zohledňovat sociální aspekty při zadávání VZ, [online]. [vid. 14. června 2014]. Dostupné z: http://www.portalvz.cz/getmedia/d6b048ec-856b-4ee0-a1c1-1c547ad15b78/PRUVODCE-socialne-citlive-nakupovani-KZ

${ }^{3}$ Evropská komise, Sociální nakupování. Průvodce zohledňováním sociálních hledisek při zadáváni veřejných zakázek, [online]. [vid. 14. června 2014]. Dostupné z: file:///C:/Users/uzivatel/Downloads/KE3210584CSC\%20(3).pdf

${ }^{4}$ Evropská komise, Pracovní dokument pro zaměstnance Komise, sociálně citlivé nakupování: prùvodce jak zohledňovat sociálni aspekty při zadávání VZ, [online]. [vid. 14. června 2014]. Dostupné z: http://www.portalvz.cz/getmedia/d6b048ec-856b-4ee0-a1c1-1c547ad15b78/PRUVODCE-socialne-citlive-nakupovani-KZ
} 
Mimo to získalo Malmö v roce 2006 jako první švédské město statut fairtradové město. V roce 2013 město zahájilo pilotní projekt zaměřený na zvýšení zaměstnanosti dlouhodobě nezaměstnaných a potírání nelegální práce (Melková 2014, s. 69). V rámci členských států EU, krátce zmíním rovněž Českou republiku, která nepatř́ ke špičkám EU v tomto odvětví, ale společensky (hlavně sociálně) odpovědné zadávání veřejných zakázek začíná být čím dále, tím více rozšiřreným institutem. Se společensky odpovědným zadáváním veřejných zakázek se můžeme setkat např. v Karlovarském kraji, kde byla uplatněna podmínka zaměstnávání $10 \%$ dlouhodobě nezaměstnaných osob na veřejné zakázce „Realizace opatření k omezení výskytu invazních rostlin“ v hodnotě 120 milionů Kč, dále ve městě Břeclav je tato podmínka uplatněna při plánované stavbě azylového domu pro jednotlivce a pro rodiny, také vedení města Kadaň počítá $\mathrm{s}$ uplatněním podmínky zaměstnávání $10 \%$ dlouhodobě nezaměstnaných osob na rekonstrukci domu č.p.169 v Prunéřově na sociální byty. Město Most uplatnilo podmínku zaměstnávání $10 \%$ dlouhodobě nezaměstnaných osob u veřejných zakázek vypsaných na rekonstrukce panelových domů a úklid na sídlišti Chanov (v r. 2010 a v r. 2012), kde nezaměstnanost dosahuje $90 \%$ a u jedné veřejné zakázky vypsané na úklid prostor Magistrátu města Mostu.

\section{Sledování úrovně ekologizace v EU (studie, kterou Evropská komise uveřejnila v r. 2012)}

Ve zprávě z roku 2008 "Zadávání veřejných zakázek v zájmu lepšího životního prostředí" Evropská komise zastávala názor, že do roku 2010 by $50 \%$ všech postupů při zadávání veřejných zakázek v EU mělo být ekologicky odpovědné. "Zelený" charakter, jak je uvedeno v dokumentu, znamená dodržování schválených společných základních kritérií, které byly vyvinuty pro deset prioritních skupin výrobků/služeb.

Deset prioritních skupin výrobků/služeb: stavebnictví, stravovací a cateringové služby, doprava a dopravní služby, spotřeba energie, kancelářské potřeby a počítače, oděvy a další textil, polygrafické služby, nábytek, čisticí prostředky a úklidové služby, zahradnictví a služby v této oblasti. Úroveň implementace se týká procenta jednotlivých postupů při zadávání veřejných zakázek, které zahrnovaly všechna základní environmentální kritéria stanovená na úrovni EU. Tato kritéria se týkají životního prostředí v různých fázích postupu při zadávání veřejných zakázek a to:

a) popisu předmětu veřejné zakázky (mohou to být různé technické specifikace. Tyto vlastnosti zahrnují vliv na životní prostředí, přizpůsobení všem požadavkům, posuzování shody, výkon, bezpečnost nebo rozměry, včetně postupů zajištění jakosti, terminologie, symbolů, přezkoušení a zkušebních metod, balení, značení nebo štítkování, návod k použití a výrobní postupy a metody.)

b) kvalifikace dodavatelů (např. technická a odborná způsobilost),

c) kritérií udělování veřejné zakázky (zakázka se zadává na základě hospodářsky nejvýhodnější nabídky $\mathrm{z}$ hlediska veřejného zadavatele, zahrnuje různá kritéria spojená s př̀edmětem dané veřejné zakázky, jako jsou kvalita, cena, technická úroveň, estetické a funkční vlastnosti, vlastnosti z hlediska vlivu na životní prostředí, provozní náklady, návratnost nákladů, záruční servis a technická pomoc, datum dodání, dodací lhůta a lhůta pro dokončení; nebo pouze na základě nejnižší ceny.)

d) podmínek realizace veřejné zakázky (Veřejní zadavatelé mohou stanovit zvláštní podmínky pro plnění zakázky za předpokladu, že jsou slučitelné s právem EU a jsou uvedeny v oznámení o zakázce nebo v zadávací dokumentaci. Podmínky, kterými se rrídí plnění zakázky, se mohou týkat zejména sociálních faktorů a životního prostředí.) 
Obrázek č. 1: Úroveň přijetí unijních kritérií z oblasti životního prostředí při zadávání veřejných zakázek v členských státech EU v roce 2011

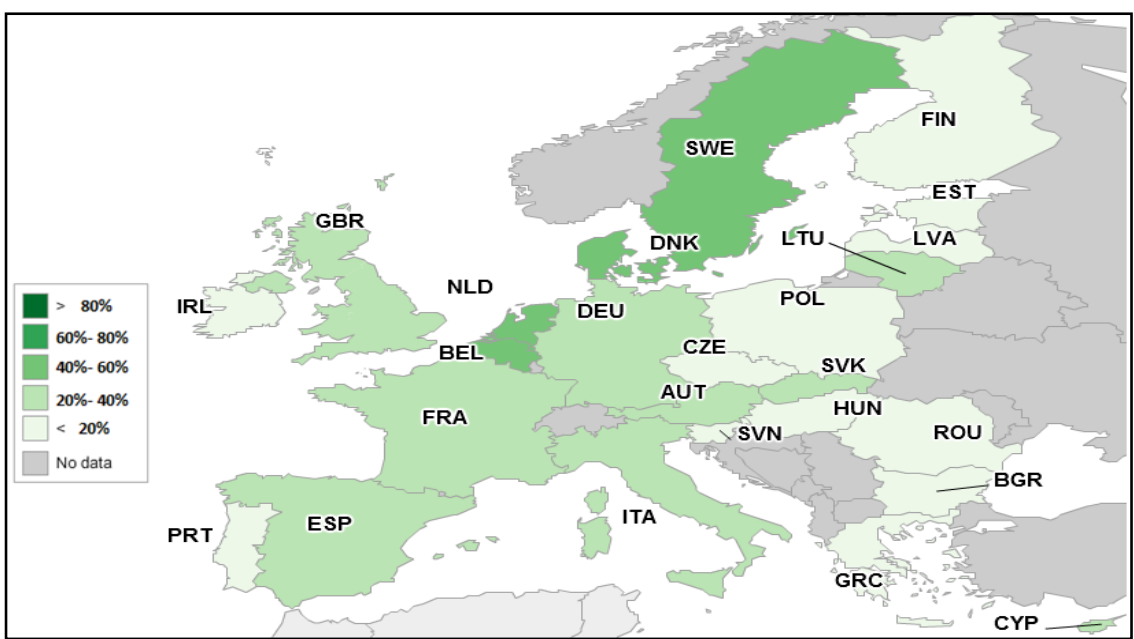

Zdroj: European Commission, DG Environment, The uptake of green public procurement in the EU 27, [online]. Brussels, 29 February 2012, [vid. 14. června 2014]. Dostupné z: file:///C:/Users/uzivatel/Desktop/CEPS-CoEGPP\%20MAIN\%20REPORT.pdf, str. 9

Obrázek znázorňuje celkovou úroveň přijetí unijních kritérií v oblasti životního prostředí při zadávání veřejných zakázek v členských státech EU pro skupiny deseti výrobků/služeb v roce 2011. Různé odstíny zelené na obrázku představují různorodou situaci, pokud se jedná o ,zelené“ veřejné zakázky v zemích EU. Čtyřmi nejlepšími státy v této kategorii jsou: Belgie, Dánsko, Nizozemsko a Švédsko (40-80\%). Ve druhé skupině zemí vyznačující se tím, že úroveň přijetí kritérií se pohybuje v rozmezí 20 - 40\%, jsou: Německo, Rakousko, Španělsko, Francie, Spojené království, Itálie, Litva, Slovensko, Kypr a Malta. Až v dvanácti zemích - Portugalsko, Irsko, Polsko, Česká republika, Finsko, Slovinsko, Mad’arsko, Rumunsko, Bulharsko, Řecko, Lotyšsko a Estonsko - úroveň využívání unijních kritérií v oblasti životního prostředí při zadávání veřejných zakázek je nižší než $20 \%$. Je třeba zdůraznit, že analýza nebere $\mathrm{v}$ úvahu Lucembursko, vzhledem k nedostatku odpovědí v průzkumu. ${ }^{5} \mathrm{~V}$ době provádění této ankety členským státem EU nebylo Chorvatsko.

\section{Nová právní úprava společensky odpovědných veřejných zakázek v Evropské unii}

28. března 2014 byly zveřejněny nové zadávací směrnice týkající se oblasti veřejných zakázek. Konkrétně se jedná o směrnici Evropského parlamentu a Rady 2014/23/EU ze dne 26. února 2014 o udělování koncesí, směrnici Evropského parlamentu a Rady 2014/24/EU ze dne 26. února 2014 o zadávání veřejných zakázek a o zrušení směrnice 2004/18/ES a také směrnici Evropského parlamentu a Rady 2014/25/EU ze dne 26. února 2014 o zadávání zakázek subjekty působícími $\mathrm{v}$ odvětví vodního hospodářství, energetiky, dopravy a poštovních služeb a o zrušení směrnice 2004/17/ES. Lhůta pro jejich implementaci do národních legislativ členských států je stanovena do 18. dubna 2016. Jedním z cílů těchto směrnic je právě posílení možnosti zadavatelů uplatňovat zvláštní podmínky v sociální a environmentální oblasti.

\footnotetext{
${ }^{5}$ Urząd Zamówień Publicznych, Krajowy Plan Działania w zakresie zrównoważonych zamówień publicznych na lata 2013-2016 (Národni akční plán pro udržitelné zadávání veřejných zakázek na obdobi 2013-2016), [online]. $\begin{array}{lllllll}\text { Warszawa } & 2012, & \text { [vid. } & 14 . & \text { června } & \text { Dostupné }\end{array}$ file://C:/Users/uzivatel/Downloads/KPD_ZZP_17.04.2013\%20(2).pdf
} 
Nejdůležitější změny a novinky, které se týkají společensky odpovědného zadávání veřejných zakázek, jsou následující:

- Rozšíření rozsahu tzv. vyhrazených veřejných zakázek: Členské státy mohou vyhradit právo na účast $\mathrm{v}$ zadávacím řízení chráněným dílnám a hospodářským subjektům, jejichž hlavním cílem je sociální a profesní začlenění osob s postižením nebo osob znevýhodněných, nebo mohou vyhradit plnění veřejných zakázek v rámci programů chráněného zaměstnání, pokud alespoň 30 \% zaměstnanců těchto dílen, hospodářských subjektů nebo programů jsou osoby s postižením nebo osoby znevýhodněné (ve směrnici č. 2004/18/ES je uvedeno, že většina dotčených zaměstnanců jsou zdravotně postižené osoby, viz str. 3 tohoto článku)

- Možnost požadovat štítky. Pokud veřejní zadavatelé mají v úmyslu nakoupit stavební práce, dodávky nebo služby, které mají zvláštní environmentální, sociální nebo jiné vlastnosti, mohou $\mathrm{v}$ technických specifikacích, kritériích pro zadání nebo podmínkách plnění veřejné zakázky vyžadovat zvláštní štítek coby doklad, že př́slušné stavební práce, služby nebo dodávky požadovaným vlastnostem vyhovují (toto je nové ustanovení v čl. 43 směrnice Evropského parlamentu a Rady 2014/24/EU ze dne 26. února 2014 o zadávání veřejných zakázek a o zrušení směrnice 2004/18/ES)

- Náklady životního cyklu. Pokud veřejní zadavatelé posuzují náklady podle př́stupu vycházejícího z nákladů životního cyklu, uvedou v zadávací dokumentaci údaje, které mají uchazeči poskytnout, a metodu, kterou veřejný zadavatel použije ke stanovení nákladů životního cyklu na základě těchto údajů. Náklady zahrnují v příslušném rozsahu všechny následující náklady v průběhu životního cyklu výrobku, služby nebo stavebních prací nebo části těchto nákladů. Jsou to náklady nesené veřejným zadavatelem nebo jinými uživateli, jako např.: náklady související s pořízením, náklady související s využíváním, jako je spotřeba energie a jiných zdrojů, náklady na údržbu, náklady spojené s koncem životnosti, jako jsou náklady na sběr a recyklaci, náklady způsobené environmentálními externalitami, které jsou spojeny s výrobkem, službou nebo stavebními pracemi v průběhu jejich životního cyklu, pokud lze vyčíslit a ověřit jejich peněžní hodnotu (toto je nové ustanovení v čl. 68 směrnice Evropského parlamentu a Rady 2014/24/EU ze dne 26. února 2014 o zadávání veřejných zakázek a o zrušení směrnice 2004/18/ES)

\section{Společensky odpovědné zadávání veřejných zakázek v Polské republice}

Veřejné zakázky v Polské republice jsou upraveny zákonem ze dne 29. ledna 2004 Prawo zamówień publicznych Dz. U. z 2010 r. Nr 113, poz. 759 Polské republiky, jak již v úvodu bylo zmíněno (dále zákon o veřejných zakázkách Polské republiky). Společensky odpovědné veřejné zakázky byly zavedeny do právního řádu Polské republiky teprve v roce 2009, tímto jsou relativně mladým institutem, nejsou běžné a proto mohou způsobovat obtíže. Společensky odpovědné zadávání veřejných zakázek není povinné, a proto i tato skutečnost může být důvodem jejich malého využití v Polsku. V tomto ohledu se zdají být nezbytná opatření k širrení poznatků na toto téma. Proto v roce 2010 Úřad pro veřejné zakázky Polské republiky vypracoval Národní akční plán pro udržitelné zadávání veřejných zakázek na období 2010-2012. Byly v něm stanoveny následující obecné cíle: zvýšení úrovně sociálně odpovědných veřejných zakázek na vnitrostátní úroveň do $10 \%$ ze všech zakázek udělených v Polské republice a úroveň ,zelených“ veřejných zakázek má být zvýšena do $20 \%$ ze všech zakázek udělených v Polské republice. Toho mělo být dosaženo mimo jiné školením, publikacemi, letáky atd.

V zákoně o veřejných zakázkách Polské republiky najdeme mnoho ustanovení týkajících se společensky odpovědného zadávání veřejných zakázek, které byly implementovány do polského právního řádu. Dle čl. 22 odst. 2 stanoví-li tak zadavatel v oznámení či výzvě o zahájení zadávacího řízení, může se zadávacího řízení účastnit pouze zájemce, který 
zaměstnává více než $50 \%$ osob se zdravotním postižením (z celkového počtu zaměstnanců zájemce) podle zvláštního právního předpisu nebo př́slušných ustanovení členských států Evropské unie nebo Evropského hospodářského prostoru (Pieróg 2012).

Dle čl. 29 odst. 4 zadavatel může v zadávacích podmínkách uvést požadavky týkající se zvláštních podmínek na plnění veřejné zakázky, jedná se o zaměstnání:

a) nezaměstnaných nebo mladistvých v souvislosti s přípravou na povolání,

b) osob se zdravotním postižením a

c) jiných osob, uvedených v právních předpisech o sociálním zaměstnání. Těmito osobami jsou bezdomovci, závislí na alkoholu, drogách, psychicky nemocní, osoby propuštěné z věznic, kteří mají problémy s integrací zpět do společnosti či také uprchlíci.

Zadavatel také může v zadávacích podmínkách uvést požadavky týkající se vzniku vzdělávacího fondu, kde platba zaměstnavatelů bude alespoň čtyřnásobkem nejnižší platby stanovené $\mathrm{v}$ předpisech o podpoře zaměstnanosti a institucích trhu práce. Zadavatel také může v zadávacích podmínkách uvést požadavky týkající se zvýšení př́íspěvku do vzdělávacího fondu. Zvláštní podmínka má být zveřejněna $\mathrm{v}$ oznámení o zahájení zadávacího řízení nebo ve výzvě o zahájení zadávacího řízení (Dzierżanowski, Jerzykowski, Stachowiak 2012).

Dle čl. 36 odst. 2 bod 9, pokud zadavatel v zadávacích podmínkách uvádí požadavky týkající se zvláštních podmínek na plnění veřejné zakázky, musí určit zejména:

a) počet osob, které je nutné zaměstnat a dobu jejich zaměstnání

b) způsob dokumentace jejich zaměstnávání, vytvoření nebo zvýšení vzdělávacího fondu a

c) pravomoci zadavatele ve věci kontroly plnění dodavatelem těchto požadavků a uplatňování sankcí v př́ípadě jejich neplnění.

Společensky odpovědné zadávání veřejných zakázek v Polské republice bylo uplatněno v mnoha obcí/městech, takových jak: Gdynia, Gdańsk, Bydgoszcz, Brzeziny, Bytom, Wrocław, Częstochowa, Szczecin, Toruń, Łódź či Krakov. Usnesením č. LXII/957/10 rady města Bydgoszczy ze dne 24. března 2010 bylo vytvořeno sociální družstvo ${ }^{6}$ „Bydgoszczanka“. Jeho hlavním cílem bylo: vytvoření pracovních příležitostí pro nezaměstnané, organizování nezaměstnaným společensky užitečné práce, organizování práce pro sociální účely pro bývalé trestance. „Bydgoszczance" se podařilo získat mnoho veřejných zakázek např.: jarní čistění chodníků, údržba hrází, oprava chodníků, renovace hřišti, odklízení sněhu, údržba zeleně. Tímto "Bydgoszczanka" dává šanci a možnost pracovat nezaměstnaným. Ve městě Bytom usnesením č. 179 ze dne 11. května 2011 ve věci uplatňování ustanovení týkajících se společensky odpovědného zadávání veřejných zakázek prezident města Bytom určil praktická opatření realizace zadávání společensky odpovědných veřejných zakázek. V řízení o zadávání veřejných zakázek, jejichž hodnota nepřesahuje 14000 euro, doporučuje použití tzv. společensky odpovědné zadávání veřejných zakázek. Město Brzeziny je polským lídrem, pokud se jedná o společensky odpovědné zadávání veřejných zakázek. Na konci roku 2013 byla provedena analýza, ze které vyplynulo, že na lokálním trhu je kolem 300 zaměstnaných osob se zdravotním postižením, které byly zaměstnány jen díky společensky odpovědnému zadávání veřejných zakázek. V městě Brzeziny funguje také sociální podnik (má při svém podnikání za cíl zaměstnávat občany znevýhodněné na běžném pracovním trhu), se kterým město úzce spolupracuje, a které pro

\footnotetext{
${ }^{6}$ Sociálním družstvem je družstvo, které soustavně vyvíjí obecně prospěšné činnosti směřující na podporu sociální soudržnosti za účelem pracovní a sociální integrace znevýhodněných osob do společnosti s přednostním uspokojováním místních potřeb a využíváním místních zdrojů podle místa sídla a působnosti sociálního družstva, zejména $\mathrm{v}$ oblasti vytváření pracovních př́ležitostí, sociálních služeb a zdravotní péče, vzdělávání, bydlení a trvale udržitelného rozvoje (§ 758 zákona č 90/2012 Sb. o obchodních korporacích)
} 
něho vykonává služby v oblasti údržby zeleně, údržby cest a chodníků či provozování útulku pro zviŕrata. V roce 2013 město začalo pracovat také v oblasti komunálního odpadu a počíta se s vytvořením 30 pracovních míst pro dlouhodobě nezaměstnané osoby ze sociálně vyloučeného prostředí.

Př́klad společensky odpovědného zadávání veřejných zakázek v Polské republice:

Zadavatel: město Brzeziny

Předmět veřejné zakázky: údržba a opravy ve městě Brzeziny (rekonstrukce cest a chodníků, úprava silničního sjezdu, organizace dopravy týkající se obnovy existujícího a vytváření nového dopravního značení)

Druh veřejné zakázky: služba

Forma veřejné zakázky: otevřené rrízení

Datum zveřejnění: 18.2.2011

Datum odevzdání nabídek do: 28.2.2011, 11:30 hod.

V zadávací dokumentaci byla zavedena následující položka: Nejméně 3 osoby, které se budou podílet na plnění zakázky, přijme dodavatel do pracovního poměru z řad osob se zdravotním postižením, a to minimálně na dobu celého trvání plnění veřejné zakázky. $\mathrm{V}$ př́padě rozvázání pracovního poměru ze strany osoby se zdravotním postižením nebo dodavatele před uplynutím této lhůty, je nutné, aby dodavatel nahradil volné místo jinou osobou se zdravotním postižením.“ Zadavatel má právo kdykoli v průběhu trvání plnění veřejné zakázky požádat dodavatele, aby předložil př́slušnou dokumentaci týkající zaměstnání nezaměstnaných osob, a dodavatel je povinen neprodleně tuto dokumentaci předložit zadavateli. V př́padě, kdy dodavatel nezaměstná určený počet osob se zdravotním postižením, bude povinen zaplatit smluvní pokutu zadavateli.

Zadavatel obdržel 3 nabídky, z toho 2 byly hodnoceny a 1 byla vyloučena.

Vítěz veřejné zakázky: Park i Ogród Jarosław Biernat, Miedniewice 81, 96-100 Skierniewice, kraj/woj. łódzkie.

Minimální nabídková cena: 337 296,42 zł

Maximální nabídková cena: 357439,67 zł

Nabídková cena vítěze: 337 296,42 zł

Smluvní vztah byl uzavřen dne: 17.03.2011.

Veřejná zakázka trvala od 1. dubna 2011 do 30. ř́ína 2012.

Přínosem této veřejné zakázky bylo samozřejmě především zaměstnání 3 osob se zdravotním postižením. Př́inos to je rovněž pro zaměstnavatele, který zaměstnává osoby se zdravotním postižením, tento zaměstnavatel má nárok na měsíční dotace na mzdy zaměstnance se zdravotním postižením ze Státního fondu pro rehabilitaci zdravotně postižených osob (PFRON), pokud zaměstnanec byl zařazen do evidence zaměstnaných osob se zdravotním postižením vedených PFRON. Zaměstnavatel může rovněž získat finanční prostředky na zaplacení osob se zdravotním postižením zaměstnaných na základě pracovní smlouvy.

\section{Ekologizace veřejných zakázek v Polské republice}

Pro následující analýzu byly zvoleny roky 2009-2012. Jak již bylo uvedeno výše, dle Národního akčního plánu pro udržitelné zadávání veřejných zakázek na období 2010-2012 měla být úroveň „zelených“ veřejných zakázek zvýšena do $20 \%$ ze všech zakázek udělených v Polské republice. V této praktické části vycházím z výsledků dat zjištěných na základě sekundárního výzkumu. Sekundární výzkum je založen na informacích z oficiálních internetových stránek Úřadu pro veřejné zakázky Polské republiky či Národního akčního plánu pro udržitelné zadávání veřejných zakázek. 
Obrázek č. 2: Úroveň ekologizace veřejných zakázek v Polské republice v letech 2009-2012 $\mathrm{v}$ procentech

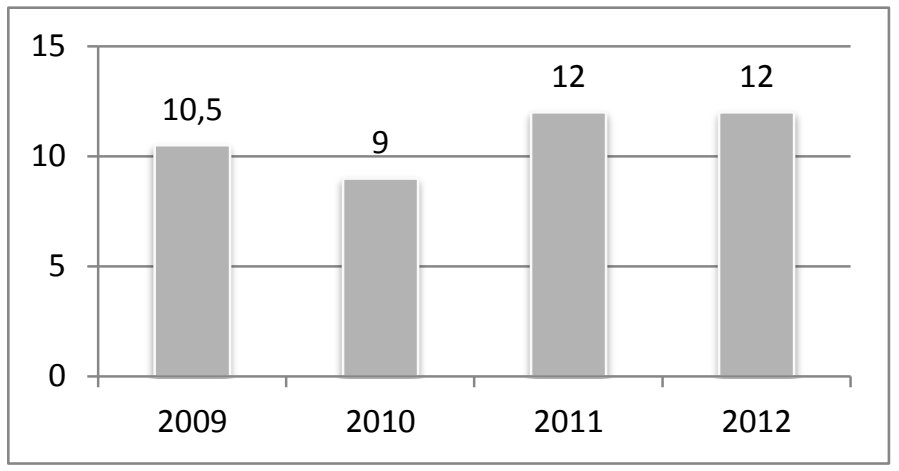

Zdroj: vlastní zpracování, údaje čerpány z „Urząd Zamówień Publicznych, Krajowy Plan Działania w zakresie zrównoważonych zamówień publicznych na lata 2013-2016“

Výsledky ukázaly, že v roce 2009 10,5\% veřejných zakázek bylo tzv. „zelených“. Tzv. „zelené“ veřejné zakázky zaznamenaly narůst, nebot' (pro zajímavost) ještě v roce 2006 úroveň ekologizace veřejných zakázek v Polské republice činila pouhé 4\%. V roce 2009 se tzv. „zelené veřejné zakázky“ týkaly mimo jiné modernizace budov (tj. výměna oken, zateplení budovy), rekonstrukce vodovodů a kanalizací (např. instalace kompresorových stanic, čerpacích stanic atd.). Příkladem veřejné zakázky týkající se poskytování služeb v oblasti životního prostředí je vypracování územního plánu obsahujícího posouzení vlivu na životní prostředí. V roce 2010 Úřad pro veřejné zakázky pokračoval v analytické činnosti týkající se oblasti environmentálních hledisek při zadávání veřejných zakázek a vypracoval plánovací dokument. Úroveň ekologizace veřejných zakázek v roce 2010 byla $9 \%$. V roce 2011 12\% veřejných zakázek bylo tzv. ,zelených“. Stejně tak v roce 2012 úroveň ekologizace veřejných zakázek byla 12\%. V roce 2012 v porovnání s rokem 2009 došlo k nárůstu v zadávání „zelených“ veřejných zakázek. „Zelené“ veřejné zakázky ale stále zůstávají na nižší úrovni než ta, která je uvedena ve zprávě Evropské komise z roku 2008 tj. 50 \% (viz str. 5 tohoto článku) a také než úroveň, která je uvedena v Národním akčním plánu pro udržitelné zadávání veřejných zakázek na období 2010-2012 tj. 20\%. Mírný nárůst environmentálních aspektů $\mathrm{v}$ rámci rrízení o zadání veřejné zakázky vyplývá $\mathrm{z}$ růstu zájmů o problematiku životního prostředí ze strany zadavatele a z ochoty při realizaci zadávání veřejných zakázek čerpat ze zásad trvale udržitelného rozvoje.

Obrázek č. 3: Hodnota „zelených“ veřejných zakázek v miliardách zlotých

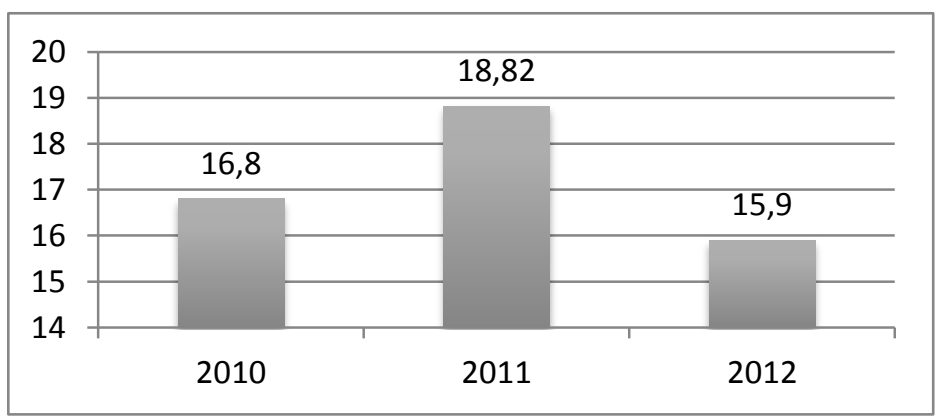

Zdroj: vlastní zpracování, údaje čerpány z „Urząd Zamówień Publicznych, Krajowy Plan Działania w zakresie zrównoważonych zamówień publicznych na lata 2013-2016“ 
Hodnota „zelených“ veřejných zakázek v roce 2010 byla 16,8 mld. zlotých, v roce 2011 18,82 mld. zlotých a v roce 2012 - 15,9 mld. zlotých. Pokles hodnoty „zelených“ veřejných zakázek v roce 2012 byl způsoben poklesem hodnoty všech veřejných zakázek v Polsku $\mathrm{v}$ roce 2012.

\section{Budoucnost ,zelených“ veřejných zakázek v Polské republice}

Vzhledem k jistému pokroku v této oblasti, je nezbytné, aby i nadále probíhala školení, konference, semináře a jiné aktivity mezi zástupci zadavatelů a docházelo $\mathrm{k}$ přenesení teoretických znalostí z této oblasti do praxe. Podle Národního akčního plánu pro udržitelné veřejné zakázky v letech 2013-2016, Úřad pro veřejné zakázky dále plánuje sledování stupně začlenění environmentálních hledisek do postupu při zadávání veřejných zakázek. Přes řadu činností prováděných v rámci akčního plánu na období 2010-2012, se nepodařilo zvýšit podíl „zelených“ veřejných zakázek na výši $20 \%$. Fakultativnost (až na výjimky) při zohledňování zadavatelem otázek týkajících se „zelených“ veřejných zakázek a nedostatek znalosti, technických specifikací předmětu veřejné zakázky, je brzdou skutečného růstu „zelených“ veřejných zakázek. To snižuje efektivitu při vytváření a udržování „zelených“ postojů mezi polskými zadavateli. Je tedy předpoklad si zachovat úroveň $20 \%$ „zelených“ veřejných zakázek jako cíl pro realizaci v příštím časovém období. Dalším cílem je stimulovat rozvoj trhu tím, že vytvoří poptávku po výrobcích, které splňují vysoké standardy ochrany životního prostředí a inovativních ekologických technologií ve veřejné správě.

\section{Sociální aspekty př̀i zadávání veřejných zakázek v Polské republice}

Pro následující analýzu byly zvoleny roky 2010-2012. Dle Národního akčního plánu pro udržitelné zadávání veřejných zakázek na období 2010-2012 úroveň sociálně odpovědných veřejných zakázek měla být zvýšena do $10 \%$ ze všech zakázek udělených v Polské republice.

Obrázek č. 4: Úroveň sociálně odpovědných veřejných zakázek v Polské republice v letech 2010-2012 v procentech

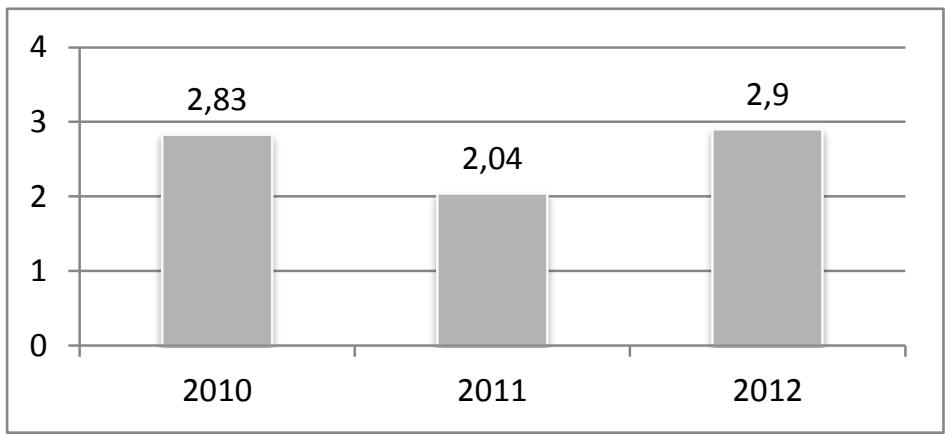

Zdroj: vlastní zpracování, údaje čerpány z „Urząd Zamówień Publicznych, Krajowy Plan Działania w zakresie zrównoważonych zamówień publicznych na lata 2013-2016“

Průměrná úroveň sociálně odpovědných veřejných zakázek v Polsku v roce 2010 činila $2,83 \%$, v roce $2011-2,04 \%$ a v roce $2012-2,9 \%$. 
Obrázek č. 5: Hodnota sociálně odpovědných veřejných zakázek v miliardách zlotých

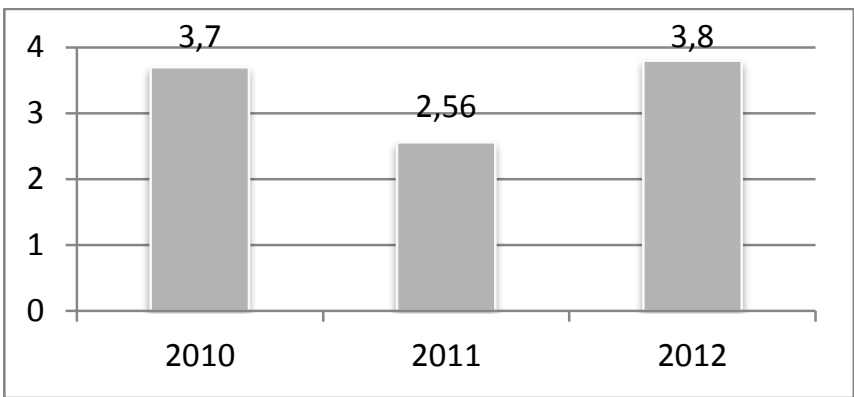

Zdroj: vlastní zpracování, údaje čerpány z „Urząd Zamówień Publicznych, Krajowy Plan Działania w zakresie zrównoważonych zamówień publicznych na lata 2013-2016“

Hodnota sociálně odpovědných veřejných zakázek v roce 2010 byla 3,7 mld. zlotých, v roce $2011-2,56$ mld. zlotých a v roce $2012-3,8$ mld. zlotých.

Akční plán na období 2010-2012 se nepodařilo splnit. Důvody, proč se tak stalo, jsou podobné jako při ekologizaci veřejných zakázek a to fakultativnost př́ zohledňování zadavatelem otázek týkajících se sociálně odpovědného zadávání veřejných zakázek či přesvědčení, že při použití sociálně odpovědného zadávání veřejných zakázek nelze dosáhnout ekonomickou převahu. Z tohoto důvodu v akčním plánu na období 2013-2016 se předpokládá dosáhnout za cíl stejné úrovně, jak tomu bylo vakčním plánu na období 2010-2012, tj. 10\% úrovně sociálně odpovědných veřejných zakázek ze všech zakázek udělených v Polské republice. Dalším cílem je podpora realizace cílů sociální politiky s uplatněním veřejných zakázek.

\section{Výhody společensky odpovědného zadávání}

Pokud se jedná o výhody společensky odpovědného zadávání, tak jsou to bezpochyby dotace pro zaměstnavatele na zaměstnávání osob dlouhodobě nezaměstnaných či již zmíněných zdravotně postižených osob. Tyto dotace mají pomoci firmám i obcím udržet a také vytvořit nová pracovní místa.

$\mathrm{V}$ rámci aktivní politiky zaměstnanosti ČR mohou úřady práce poskytovat mj. i tyto dotace dle zákona č. 435/2004 Sb., o zaměstnanosti, a to k tíži státního rozpočtu podle tzv. rozpočtových pravidel:

- př́spěvek na vytvoření chráněného pracovního místa nebo chráněné pracovní dílny,

- př́spěvek na podporu zaměstnávání osob se zdravotním postižením,

- hmotná podpora nových pracovních míst, rekvalifikací a školení v rámci investičních pobídek,

- př́spěvek na zřízení společensky účelného pracovního místa (pracovní místa, která zaměstnavatel zřizuje nebo vyhrazuje na základě dohody s Úřadem práce a obsazuje uchazeči o zaměstnání, kterým nelze zajistit pracovní uplatnění jiným způsobem),

- př́spěvek na zapracování (může Úřad práce poskytnout zaměstnavateli na základě s ním uzavřené dohody, pokud zaměstnavatel přijímá do pracovního poměru uchazeče

o zaměstnání, kterému krajská pobočka Ứřadu práce věnuje zvýšenou péči).

Na tyto dotace není právní nárok a každý si o ně musí samostatně požádat u př́íslušného úřadu práce.

Rovněž v Polské republice zaměstnavatelé, kteří se rozhodnou zaměstnat nezaměstnané osoby evidované na úřadu práce, mohou mít $\mathrm{v}$ tomto ohledu velké výhody. Jedná se hlavně o vrácení 
části částky vynaložené na mzdy a sociální pojištění. Náhrady poskytuje starosta, respektive okresní úráad práce z Fondu práce. Kromě toho úřady práce přijímají peníze na náhrady ze státního rozpočtu a Evropské unie. Další dotací je již zmíněna (viz str. 9), dotace na mzdy zaměstnance se zdravotním postižením ze Státního fondu pro rehabilitaci zdravotně postižených osob (PFRON).

\section{Závěr}

Společensky odpovědné zadávání veřejných zakázek je relativně mladým institutem, jehož účel je ale nade vší pochybnost. V článku jsem zmapovala problematiku společensky odpovědného zadávání veřejných zakázek v Evropské unii z hlediska historie, směrnice Evropského parlamentu a Rady č. 2004/18/ES ze dne 31. března 2004, o koordinaci postupů při zadávání veřejných zakázek na stavební práce, dodávky a služby, ve znění pozdějších předpisů a také $\mathrm{z}$ hlediska nových směrnic, především směrnice Evropského parlamentu a Rady 2014/24/EU ze dne 26. února 2014 o zadávání veřejných zakázek a o zrušení směrnice 2004/18/ES, která má být implementována do národních legislativ členských států EU do 18. dubna 2016. Článek byl doplněn krátkými př́íklady týkajícími se společensky odpovědného zadávání veřejných zakázek v Polsku a v jiných vybraných členských státech EU (konkrétně Francii, Velké Británii, Švédsku a České republice). V části týkající se ekologizace veřejných zakázek a sociálně odpovědného zadávání v Polské republice vycházím z výsledků dat zjištěných na základě sekundárního výzkumu. Sekundární výzkum je založen na informacích z oficiálních internetových stránek Úřadu pro veřejné zakázky Polské republiky či Národního akčního plánu pro udržitelné zadávání veřejných zakázek. Provedla jsem analýzu a graficky jsem znázornila a zhodnotila úroveň ekologizace veřejných zakázek v Polsku v letech 20092012, úroveň sociálně odpovědného zadávání veřejných zakázek v Polsku v letech 2010-2012 či úroveň přijetí unijních kritérií $\mathrm{z}$ oblasti životního prostředí ve veřejných zakázkách v členských státech EU v roce 2011. Cílem výzkumu bylo rovněž dokázat, že společensky odpovědné zadávání veřejných zakázek má v legislativě EU své opodstatnění a je využíváno v praxi, pří řešení problematiky dlouhodobé nezaměstnanosti, zaměstnanosti osob se zdravotním postižením či uplatňování environmentálních kritérií v zadávacím řízení.

Budoucnost společensky odpovědného zadávání veřejných zakázek je velmi př́iznivá i z důvodu již zmíněných nových směrnic EU, které by měly ještě ve větší míre podpořit implementaci sociálních a environmentálních cílů do zadávání veřejných zakázek ve všech členských státech Evropské unie. Z výzkumu je rovněž patrné, že v Polské republice se sice v posledních letech nepodařilo dosáhnout úrovně, dle cíle uvedeného v Národním akčním plánu pro udržitelné zadávání veřejných zakázek na období 2010-2012, u sociálně odpovědných veřejných zakázek $10 \%$ ze všech zakázek udělených v Polsku a u environmentálních veřejných zakázek $20 \%$ ze všech zakázek udělených v Polsku. Avšak Národní akční plán pro udržitelné zadávání veřejných zakázek na období 2013-2016 si dál tyto úrovně za cíl znovu společně s podporou realizace cílů sociální politiky s uplatněním veřejných zakázek či vytvářením poptávky po výrobcích, které splňují vysoké standardy ochrany životního prostředí.

\section{Literatura}

[1] DZIERŻANOWSKI, W., J. JERZYKOWSKI a M. STACHOWIAK, 2012. Prawo zamówień publicznych. Komentarz, wydanie 2. Kraków: Wolters Kluwer. ISBN 978-83264-3851-6. 
[2] Interpretační sdělení Komise o právech Společenství platných pro zadávání veřejných zakázek a možnostech začlenění společenských hledisek do zadávání veřejných zakázek KOM (2001) 566 v konečném znění ze dne 15. 10. 2001.

[3] Krajowy Plan Działania w zakresie zrównoważonych zamówień publicznych na lata 2010-2012 (Národního akčního plánu pro udržitelné zadávání veřejných zakázek na období 2010-2012.) Urząd Zamówień Publicznych [online]. [vid. 14. června 2014]. Dostupné z: http://www.cleanvehicle.eu/fileadmin/downloads/polen/Krajowy_Plan_Dzia \%C5\%82a\%C5\%84_w_zakresie_zr\%C3\%B3wnowa\%C5\%9Conych_zam\%C3\%B3wie \%C5\%84_publicznych_na_lata_2010-2012.pdf

[4] Krajowy Plan Działania w zakresie zrównoważonych zamówień publicznych na lata 2013-2016 (Národní akční plán pro udržitelné zadávání veřejných zakázek na období 2013-2016). Urząd Zamówień Publicznych [online]. [vid. 14. června 2014]. Dostupné z: file://C:/Users/uzivatel/Downloads/KPD_ZZP_17.04.2013\%20(3).pdf

[5] MELKOVÁ, G., 2014. Manuál dobrých praxí, Společensky odpovědné zadávání veřejných zakázek. Agentura pro sociální začleňování [online]. [vid. 24. března 2014]. Dostupné Z: http://www.socialni-zaclenovani.cz/dokumenty/metodiky-a-manualydobrych-praxi-asz-2014. ISBN 978-80-7440-088-9.

[6] PIERÓG, J., 2012. Prawo zamówień publicznych. Komentarz. Wydanie 11. Warszawa: C.H.Beck. ISBN 978-83-255-3441-7.

[7] Pracovní dokument pro zaměstnance Komise, sociálně citlivé nakupování: průvodce jak zohledňovat sociální aspekty při zadávání V. Evropská komise [online]. [vid. 14. června 2014]. Dostupné z: http://www.portal-vz.cz/getmedia/d6b048ec-856b-4ee0-a1c11c547ad15b78/PRUVODCE-socialne-citlive-nakupovani-KZ

[8] SCHELlEOVÁ, A. a M. PELIKÁN, 2014. Sociální a environmentální aspekty při zadávání VZ. Veřejné zakázky v praxi [online]. [vid. 14. června 2014]. Dostupné z: http://www.achourhajek.com/resources/files/36-42_soc_ek1.pdf

[9] Směrnice Evropského parlamentu a Rady č. 2004/18/ES ze dne 31. března 2004, o koordinaci postupů při zadávání veřejných zakázek na stavební práce, dodávky a služby, ve znění pozdějších předpisů [online]. [vid. 14. června 2014]. Dostupné z:http://www.portal-vz.cz/getmedia/c56beeff-3fb9-4adb-85f3-1ee3fe888e63/smernice18 -cs

[10] Směrnice Evropského parlamentu a Rady 2014/24/EU ze dne 26. února 2014 o zadávání veřejných zakázek a o zrušení směrnice 2004/18/ES [online]. [vid. 14. června 2014]. Dostupné z:http://www.portal-vz.cz/getmedia/1c79eb25-e98e-4cf9-8964-afa8df67e3f3/ Smernice-c-2014_24_EU-o-zadavani-VZ-a-o-zruseni-smernice-c-18.pdf

[11] Smlouva o založení Evropského společenství [online]. [vid. 14. června 2014]. Dostupné z: http://www.euroskop.cz/gallery/2/756-smlouva_o_es_nice.pdf

[12] Sociální nakupování. Průvodce zohledňováním sociálních hledisek při zadávání veřejných zakázek. Evropská komise [online]. [vid. 14. června 2014]. Dostupné z: file:///C:/Users/uzivatel/Downloads/KE3210584CSC\%20(3).pdf

[13] The uptake of green public procurement in the EU 27. European Commission, DG Environment [online]. Brussels, 29 February 2012 [vid. 14. června 2014]. Dostupné z: file://C:/Users/uzivatel/Desktop/CEPS-CoE-GPP\%20MAIN\%20REPORT.pdf

[14] Zákon č. 135/2004 Sb., o zaměstnanosti ve znění pozdějších předpisů. 
[15] Zákon č. 90/2012 Sb., o obchodních společnostech a družstvech (zákon o obchodních korporacích).

[16] Zákon ze dne 29. ledna 2004 Prawo zamówień publicznych Dz. U. z 2010 r. Nr 113, poz. 759 Polské republiky. Internetowy System Aktów Prawnych [online]. [vid. 14. června 2014]. Dostupné z: http://isap.sejm.gov.pl/DetailsServlet?id=WDU20040190177

[17] Zelená kniha z roku 1996, Green Paper, Public procurement in the European Union: Exploring the way forvard, Communication adopted by the Commission on 27th November 1996. 